Toplum Bilimleri Dergisi - Journal of Social Sciences

ISSN: 1306-7877 e-ISSN: 2147-5644

Şirketler İçin Hisse Halka Arz Süreci: Örnek Uygulamalar

Equity Public Offering Process for Companies: Case Studies

\author{
Halil ARSLAN \\ Kırşehir Ahievran Üniversitesi, Finans-Bankacılık ve Sigortacılık \\ Kırsehir Ahi Evran University, Finance and Banking Department \\ Kırsehir/Turkey \\ halilarslan4444@gmail.com
}

https://orcid.org/0000-0003-0853-0244

\begin{abstract}
Temur KAYHAN
İstanbul Şehir Üniversitesi, İktisadi ve İdari Bilimler Departmanı İstanbul Şehir University, Economics and Administrative Department Istanbul/Turkey kayhantemur44@gmail.com https://orcid.org/0000-0003-3738-2025

Makale Bilgisi / Article Information http://dx.doi.org/10.29238/tbd.2007.42243
\end{abstract}

Makale Türü / Article Types: Araştırma Makalesi / Research Article

Geliş Tarihi / Received: 23.03.2020

Yayın Tarihi / Published: 25 Haziran / June 2020

Yayın Sezonu / Pub Date Season: Haziran / June 2020

Cilt / Volume: 28

Sayfa / Pages: 1-14

Copyright (C) Published by Toplum Bilimleri Dergisi - Journal of Social Sciences.

All rights reserved www.toplumbilimleri.com 


\section{Şirketler İçin Hisse Halka Arz Süreci: Örnek Uygulamalar}

Öz: Sermaye piyasalarına dayalı bir ekonomide refah tabana yayılmakta, küçük birikimler ekonomiye katılmakta ve girişimcilik ruhu ile üretkenlik artmaktadır. Sermaye piyasalarının en önemli finansal aracı ise hisse senedi halka arzıdır. Hisse halka arzı, tüketicileri ekonomik kalkınmaya hem sermaye hem de bilgi anlamında dahil ederken banka finansmanında dar boğazda olan şirketler için yeni bir finansman aracı ortaya çıkarmaktadır. Çalışmamızda sermaye piyasaları profesyonelleri ve sanayi firmaları yöneticileri ile halka arza yönelik en çok merak edilen sorular ortaya konmuş ve cevapları aranmıştır. Gerçek halka arz uygulamalarının fiyat tespit raporları incelenerek son dönemde gelişen fiyatlama yaklaşımları ve halka arzların başarıları gösterilmeye çalışılmıştır. Sonuçlara göre şirketler ve profesyoneller için halka arzın en önemli faydaları elde edilen hisse senedi likiditesi, ucuz finansman ve stratejik ortak temine ön ayak olmasıdır. Şirketlerin halka arzdan kaçınmalarının en önemli nedenleri ise gizlilik seviyesinin azalması ve artan denetim olarak ortaya çıkmaktadır. Sermaye piyasalarına dayalı bir ekonomiye geçiş yapmak isteyen ilgili otoritelerin hangi noktalara gereksinim duyulacağına yönelik bilgileri sağlama açısından da çalışmamız sonuçlar üretmektedir. Halka arz süreçlerinin uygulamasına yönelik önemli bir literatüre sahip olmayan akademik dünya için çalışmamız bir başlangıç olarak değerlendirilmekte ve halka arzların sürecine yönelik çalışmaların artması ile sektördeki yatırımcıların finansal okuryazarlık seviyelerini artırması beklenmektedir.

Anahtar Kelimeler: Sermaye Piyasaları, Halka Arz, Şirket Değerleme, Piyasa Çarpanları, Borsa İstanbul

JEL Sinıflandırması: C58, D53, E42, G11

\section{Equity Public Offering Process for Companies: Case Studies}

Abstract: In an economy based on capital markets, prosperity spreads to the bottom, small savings join the economy and productivity rises with the entrepreneurial spirit. The most important financial instrument of the capital markets is equity public offering. Equity public offering includes consumers in economic development, both in terms of capital and information, while introducing new financing channels for companies in bottleneck in bank financing. In our study, the most curious questions about public offering are presented with capital market professionals and managers of industrial companies and their answers are sought. By examining the price determination reports of real public offering practices, the recent pricing approaches and the successes of public offerings are tried to be shown. According to the results, the most important benefits of public offering for companies and professionals are the rising liquidity of stock, getting cheap financing and connecting strategic partners. The most important reasons for companies to avoid public offering are the decrease in the level of confidentiality and increased control. Our study also produces results in terms of providing information on which points of the relevant authorities will need to switch to an economy based on capital markets. Our study for the academic world, which does not have a significant literature on the implementation of public offering processes, is considered as a beginning and it is expected that investors in the sector will increase their financial literacy levels with the increase in the studies on the process of public offering.

Keywords: Capital Markets, Public Offering, Company Valuation, Market Multipliers, Borsa Istanbul

JEL Codes: C58, D53, E42, G11 


\section{GIRIŞ}

Son yıllarda sermaye piyasalarına yönelik algının pozitife dönmesiyle Türkiye'de sermaye piyasalarının derinleşmesine yönelik çalışmalarda artış görülmektedir. Bankacılığa dayalı bir ekonominin tüketim ekonomisini tetiklemesi ve bankalardan elde edilen finansmanda sınıra ulaşılması sermaye piyasalarına dayalı bir ekonomiyi ön plana çıkarmaktadır.

Halkın küçük birikimlerini ekonomiye katmak ve sermayenin tabana yayılmasını sağlamak da sermaye piyasalarının derinleşmesi ile sağlanabilmektedir. Türkiye'nin son 10 yılda önemli bir ekonomik büyüme yaşamasına rağmen artan refahı halkın hissedebilmesi için ekonomik büyümenin yoğunlaştığı şirketlere küçük paylarla da olsa ortak olması gerekmektedir. Bu durumu sağlayan tek finansal enstruman sermaye piyasalarıdır.

Sermaye piyasalarının en önemli enstrumanı ise hisse senedi halka arzıdır. Halka arz süreci yatırımcılara yapılan genel bir çağrı sonrasında yapılan satış olarak tanımlanmaktadır (Bekçi vd., 2010:34). Halka arz sürecinde yapılan satışlar anonim şirketlerinin hisse senedi, tahvil ve kira sertifikası araçları, gayrimenkul sertifikalarından oluşmaktadır. Halka arzı en çok yapılan araç ise hisse senedidir. Halka yapılan çağrıya ek olarak sadece nitelikli yatırımcılara satılan sermaye piyasası enstrümanları da bulunmaktadır. Girişim sermayesi yatırım fonu ve gayrimenkul yatırım fonu katılma payları söz konusu araçları sembolize etmektedir.

Hisse senedinin halka arzına yönelik sanayi firmalarımızın birçok bilmediği nokta olduğu gözlemlenmiştir. Çalışmamızda sanayi ve hizmet firmalarından 20'si ziyaret edilmiş ve şirket yöneticilerinin hisse halka arzına yönelik merak ettiği noktalar belirlenmiştir. Aracı kurum ve portföy yönetim şirketlerinden 10 sektör profesyoneli ziyaret edilmiş ve sanayi firmalarının merak ettiği sorular anketle cevaplanmaya çalışılmıştır.

Çalışmamız adım adım halka arz sürecini tanımlamakla birlikte sanayi firmalarınca sıkça sorulan soruları sektör profesyonelleri ile cevaplamaya çalışmaktadır. Ayrıca 2013 yılındaki halka arzların fiyat tespit raporları ve bağımsız denetimleri incelenerek fiyatlama metodolojileri ortaya konmaya çalışılmıştır. Daha sonra başarılı ve başarısız bir halka arzın örneği çalışmada verilmeye çalışılmıştır. Çalışmamız halka arz gerçekleştirmek isteyen şirkey yöneticileri, yatırımcılar, resmi otorire ve akademisyenler için sektördeki problemleri tespit etmekte ve çözüm önerileri sunmaktadır.

Çalışmamızın ilk kısmında literatüre bir bakış gerçekleştirilirken ikinci bölümde metodoloji ve inceleme kaynakları özetlenmiştir. Üçüncü bölümde halka arz süreçleri özetlenirken halka arzların performansı ve fiyatlama metodolojileri gerçek örnekler üzerinden incelenmeye çalışmıştır. Son bölümde ise sonuçlar yorumlanmıştır.

\section{LITERATÜR TARAMASI}

Gelişmekte olan ülkelerde şirketlerin karşılaştı̆̆ı en önemli problemlerden biri finansman ihtiyacının karşılanmasıdır. Bankalardan kullanılan krediler sorunun çözümünün bir tarafı olurken özellikle uzun vadeli projelerde bankalar finansmana yanaşmamaktadırlar. Ayrıca kredi kullandırırken bankaların talep ettikleri ipotek, rehin ve teminatlar şirketler için önemli bir sorun oluşturmaktadır. Bu açıdan bakıldığında banka yolu ile temin edilemeyen finansman için en önemli bir diğer yol sermaye piyasalarında hisse ya da 
borçlanma araçları ihraçlarıdır. Özellikle hisse halka arzları yolu ile yapılan bedelli sermaye artırımları şirketlerin finansman anlamında ellerini rahatlatmaktadır. Hisse halka arzlarının şirketlerin büyümeleri için gerekli olan finansman temininde oldukça önemli olması akademik çevrelerde konu ile ilgili çok sayıda incelemenin yapılmasını ve makalelerin yayınlanmasını sağlamıştır.

Halka arzlar yatırımcıların bir anonim şirketin paylarına yönelik genel bir çağrı olarak tanımlanmaktadır (Bekçi vd., 2010: 34). Halka arz, kurucu ortağın şirketin kuruluşundan beri sarf ettiği eforunu değere dönüştürmesi için önemli bir araçtır. Şirketlerde her yıl ortalamada artırılan sermayenin yaklaşık üçte biri halka arz metodu ile karşılanmaktadır (Zingales, 1995: 425).

Halka arzlarda mevcut payların satışı olabileceği gibi karma yaklaşımda hem ortak satışı hem de şirkete nakit girişi olan sermaye artışı gerçekleştirilebilmektedir (Bekçi vd., 2010: 35).

Halka açılan bir firmayı halka kapalı bir firmadan ayıran en temel özellik, şirketin işlem gördüğü sürece yatırımcılara bilgi verme yükümlülügüudür (Karaa ve Akakçe, 2017: 377). Literatürdeki bazı çalışmalarda halka açık firma ile halka kapalı firma arasında 3 temel farklılık olduğu vurgulanmaktadır. Bunlardan ilki, halka açık firmada ortak sayısının halka kapalı firmaya göre fazla olmasıdır. İkinci önemli farklılık, değerli bir projeye yatırım yapılacağı zaman halka açık bir firmada ortakları ikna etmenin daha zor olması olarak tanımlanmaktadır. Son fark ise halka açık firmanın hisse senetlerinin tüm yatırımcılara açık bir şekilde işlem görüyor olmasıdır (Chemmanur ve Fulghieri, 1999: 250-251).

Halka arzın getirdiği ilave yükümlülüklere ek olarak faydaları literatürde önemli oranda tartışılmaktadır. Ritter (1987)'e göre aracılık ve kayıt maliyetleri; Jensen ve Meckling (1976)'e göre kamuyu aydınlatma maliyetleri ve ajan problemi halka arzın temel dezavantajları arasında yer almaktadır. Halk arzların birçok faydası literatürde tanımlanmakla birlikte Türk firmaları için halka arz, sermayenin önemli oranda kuvvetlendirilerek bankalar nezdinde pazarlık gücünü artımak olarak algılanmaktadır (Karaa ve Akakçe, 2017: 386).

Bazı halka arzların başvuru aşamasında geri çekildiği görülmekte ve bu konuda literatürde bilgi yükünün olduğu görülmektedir. Literatüre göre başvuru aşamasında geri çekilen halka arzların en temel özellikleri, ekonomideki bozulma, borsa endeksindeki gerileme, risk iştahının azalması, şirket değerinin istenilen boyutta olmaması, diğer finansman koşulları olan birleşme ve satın alma ihtimalinin güçlenmesi olarak tanımlanmaktadır (Karaa ve Akakçe, 2017: 376). Ritter ve Welch (2002)'e göre ise halka arz iptallerinin en önemli nedeni, piyasadaki risk iştahının azalmasıdır.

Kimi çalışmalarda ise halka arzdan çekilmenin daha çok ekonomik bozulmadan kaynaklandığı, halka arz başvurusunu sonlandıran firmaların aile şirketleri olmadığı ve çekilen firmaların aracı kurumların pazarlama başarısını beğenmediği sonucuna varılmaktadır (Karaa ve Akakçe, 2017: 386).

Literatürde halka arzın performansına yönelik çalışmalar da önemli bir yer tutmaktadır. Halkbank’ın halka arz sonrası performansının incelendiği bir çalışmada halka arz sonrası hissenin başarılı bir performans sergilediği, kriz dönemlerinde borsanın genel ortalamasına göre Halkbank hissesinin daha az düşüş sergilediği sonucuna varılmıştır (Bekçi vd., 2010: 50). 
Amerika'da 1980-2001 yılı arasındaki halka arzların performansını inceleyen bir çalışmaya göre halka arzda şirket hisse senetlerini alan bir yatırımcının halka arzdan sonraki 3 yılda ortalama getirisi \%22,6 olarak gerçekleşirken, aynı dönemde genel endeks performansının altında bir getiri elde edilmiştir (Ritter ve Welch, 2002: 1795).

Amerika'da son yıllarda halka arz sayılarının oldukça gerilediği gözlemlenmektedir. Kimi analistlere göre bu durum piyasadaki fiyatlamaların daha sağlıklı olması ile açıklanırken bazı çalışmalara göre bu durumun temel sebebi genel endeks getirilerinin değişmesidir. Halka arz miktarındaki gerileme endeksin genel seviyesinden ziyade endeks getirileri ile ilgilidir (Pastor ve Veronesi, 2005: 1713).

Türk borsası üzerinde yapılan çalışmalarda farklı sonuçlar elde edilmiştir. Ozer (1999)'e göre Türk borsasındaki halka arzlar, işlem görmeye başladıktan sonra ilk 3 gün endeks ortalamasının üzerinde getiri sağlamaktadır. İlk günkü getiri en yüksek getiri olmaktadır. Kıymaz (2000)'a göre söz konusu ilk gün getirileri halka arzın büyüklüğü, borsa endeksindeki risk iştahı, kurumsal yatırımcı talebi gibi değişkenlere göre farklılaşmaktadır. Bir diğer çalışmada ise hisselerin satıldığı tarih ile işlem günü arasındaki borsa endeksinin ortalama getirisi ve varyansı ilk günkü getiri başarısında oldukça etkilidir (Küçükkocaoğlu, 2008: 179).

Halka arzlarda değişik metotlarda hisse satış şekli görülürken sabit fiyatla talep toplanan halka arzlarda getirinin daha yüksek olduğu gözlemlenmektedir (Küçükkocaoğlu, 2008: 163).

Literatürdeki halka arz performans çalışmalarında genelde salt temel analizler yapılmaktadır. Halka arz edilen şirketlerin mali verilerindeki iyileşme ile getiri arasında ilişki kurulmaya çalışılmaktadır. Hisse senedi piyasasının davranışsal finans ile açıklanan değişkenlerinin de olduğu dikkate alınmalı ve halka arzların başarısı söz konusu yaklaşımla yeniden değerlendirilmelidir. Geçmişte hisse senedi piyasasından kazanç sağlamış yatırımcıların yapılan halka arzlar ve borsa getirilerinden beklentileri daha yüksek olurken geçmişte kayıp yaşamış yatırımcıların halka arzın performansından beklentisi daha düşük olabilmektedir (Karaa, 2017: 163).

Halka arzların bazı maliyetler getirdiği açıktır. Literatürdeki önemli bir çalışmanın sonucuna göre halka arz öncesinde kamuya daha çok bilgi veren, şeffaf yönetim anlayışına sahip şirketler, halka arz yapmaya karar verdiklerinde halka arz maliyetleri daha az şeffaf şirketlere göre daha düşük olabilmektedir. Aynı durum halka arz başvurusu yapıldığında izahnameye olabildiğince bilgi koymakla benzer bir durum olarak tanımlanmamaktadır (Ang ve Brau, 2002: 16).

\section{METODOLOJİ VE VERİ SETİ}

Çalışmada 20 sanayi ve hizmet firması ziyaret edilmiş ve söz konusu şirket yöneticilerinin sermaye piyasaları ve halka arza yönelik en önemli soruları not edilmiştir. Bu sorulara karşılık Bizim Menkul Değerler A.Ş., Investrade Portföy Yönetim A.Ş, Kızılay Portföy, Marbaş Menkul Değerler A.Ş.'den 10 sektör profesyoneli ile anket çalışması yapılmış ve şirketlerin halka arza yönelik soruları cevaplanmaya çalışılmıştır. Ayrıca 2013 yılında halka arzı yapılan Pegasus, Royal, Odaş, Tümosan ve Akyürek şirketlerinin bağımsız denetim, fiyat tespit raporu ve faaliyet raporları incelenerek fiyatlama metodolojileri belirlenmeye çalışılmıştır. 
Tablo 1: Ziyaret Edilen Şirketler

Ayes Çelik Hasır A.Ş.

Abkay Grup Klima Teknolojileri Sanayi ve Ticaret A.Ş.

Akyürek Tüketim Ürünleri Pazarlama Dağıtım ve Ticaret A.Ş.

Maksel İş Makinaları Ticaret A.Ş.

Natura Gıda Sanayi ve Ticaret A.Ş.

Netlog Lojistik Hizmetleri A.Ş.

Norm Ambalaj San. Tic. A.Ş.

Odaș Enerji A.Ș.

Kombassan Holding (Bera Holding) A.Ş.

Lokman Hekim Hastanesi A.Ş.

İttifak Holding A.Ș.

İdealist GYO

Birko Koyunlular Mensucat Ticaret A.Ş.

Polinas Plastik San. Ve Tic. A.Ş.

Mopaş Marketçilik Gıda ve San. Tic. A.Ş.

Akdeniz Güvenlik Hizmetleri A.Ş.

Dental Group Hospitadent

Iş11 Mühendislik A.Ş.

Birko Koyunlular Mensucat Ticaret A.Ş.

Kuralkan Bilişim Otomotiv San. ve Dıș Tic. A.S.

\section{HALKA ARZ SÜREÇLERİ}

\subsection{Halka Arzın Faydaları}

Şirketler globalleşen dünyada sermaye piyasalarından fon temin ederek daha rekabetçi olabilecekleri gibi güçlü sermayeleri ile yatırımlarını finanse edebilirler (Bekçi vd., 2010: 34). Hisse halka arzı ile şirketlerin kurucu ortakları finansman riskini dağıtabilirler. Yeni bir bedelli sermaye artışı sürecinde ana ortaklar rüçhan haklarını diğer yatırımcılara satabilirler. Halka arz sonrası şirketlerin sermaye piyasası enstrümanları daha likit olacaktır ve ikinci bir piyasa oluşacaktır. Likit bir piyasanın var olması şirketlerin varlıklarını daha değerli kılacaktır. Birçok yabancı yatırımcı için şirketlere yatırım yapmanın ilk şartı şirketin borsalara açık hisse senedinin bulunmasıdır. Borsada işlem gören şirketler yabancı yatırımcılar nezdinde şirket ile ilgili bilgileri kurumsal bir kültürde doğru bir şekilde saklayıp kamu ile paylaşan şirketler anlamına gelmektedir. Halka arzın bir diğer faydası ise şirketleri diğer paydaşları nezdinde daha bilinir kılmaktır. Şirket tedarikçileri, banka finansörleri, müşterileri ve çalışanları nezdinde kredibilitesi yüksek ve saygın bir konuma gelecektir. Halka arz süreci sonrasında şirketin denetim mekanizması güçlenecek ve şirketin kontrol mekanizması genişleyecektir. Denetlenemeyen ve kontrol edilemeyen hiçbir olgu sağlıklı yönetilemeyecektir. Halka arz sonrası aracı kurum analistleri, Sermaye Piyasası Kurulu (SPK), yatırımcılar ve bağımsız denetim firmaları şirketin operasyonel ve yasal faaliyetlerini daha yakından izleyecektir. Birçok Türk şirketi çok ortaklı olmadığı için sağlıklı ve anlaşılabilir raporlama standartları üzerine bir çalışma yürütmemektedir. Çoklu ortaklı yapıda tüm ortakların şirketin faaliyetlerini anlayabilmesi ve analiz edebilmesi için raporlama standartlarının gelişmesi gerekecektir. Çoklu ortaklı yapıda firma daha çok sermaye elde edebileceği için yeni sermayenin kaldıracı ile çok daha büyük yatırımlara girişebilecek ve karlılığını artırabilecektir (Bekçi vd., 2010: 35). 
Bizim Menkul Değerler A.Ş., Investrade Portföy Yönetim A.Ş, Kızılay Portföy, Marbaş Menkul Değerler A.Ş.'den 10 kurumsal finansman çalışanı ile yapılan anket çalışmasında halka arzın şirketler için faydaları notlandırılmış ve ağırlıklı notlar aşağıdaki tabloda gösterilmiştir. Anket çalışmasında ilk sırayı ucuz finansman almıştır.

Tablo 2: Halka Arzın Faydaları

\begin{tabular}{lr} 
Likidite & 7 \\
Kurumsallaşma & 5 \\
Stratejik Ortaklık & 7 \\
Bilinirlik & 5 \\
Denetim & 4 \\
Raporlama Standartları & 5 \\
Finansman Riskinin Dağıtılması & 6 \\
Ucuz Finansman & 8 \\
\hline
\end{tabular}

Kaynak: Sektör Profesyonelleri Çalışması

\section{2. Türk Şirketlerinin Halka Arzdan Kaçınma Nedenleri}

Çalışmada sanayi ve hizmet sektörü firmalarından 20 tanesi ile şirket yönetici ziyaretleri gerçekleştirilmiş ve şirketlerin halka arzdan kaçınmaları için temel faktörleri skorlamaları istenmiştir. En çok öne çıkan sebepler şirketlerin halka arz sonrası rakipleri, vergisel otorite, tedarikçileri ve müşterileri nezdinde azalan gizlilik olarak görülmektedir. Şirketlerin bilgilerini kamuya açıklamaları şirketler nezdinde ticari sırların ortaya çıkması şeklinde algılanmaktadır. Aslında mevcut mali verilerde yer alan kayıt dışı verilerin de bu algıda etkisi olduğu düşünülebilir. 500 sanayi firmasındaki şirketlerin sermayeye olan ihtiyaçlarının düşük olması ve bankacılık ile finansmanın daha az bürokratik engel ortaya çıkarması da bir diğer sebep olarak görülebilir. Halka arz sonrası bağımsız denetim zorunluluğu ve SPK'nın otoritesine firmalar girmek istememektedir.

\begin{tabular}{lr} 
Tablo 3: Halka Arzdan Kaçınma Nedenleri & Skor \\
\hline Denetim & 8
\end{tabular}

Sermaye İhtiyacının Olmaması $\quad 7$

Gizlilik Seviyesinin Azalması

Bürokratik Artan Yük 7

Mevcut Mali Verilerin Şeffaf Olmaması 4

Halka Arza Hazır Olmamak 5

Olumsuz Piyasa Şartları 4

Düşük Hisse Fiyatlaması $\quad 5$

Kaynak: Şirket Ziyareti Verileri 


\section{3. Sıkça Sorulan Sorular}

Sanayi ve hizmet sektöründen 20 firma ziyaretinde ortaya çıkan temel sorular dikkat çekmiştir. Şirketler daha çok halka arzın maliyetini merak etmektedirler. Aracı kurum profesyonelleri ile yapılan ziyaret ve anket çalışmalarında sektör profesyonelleri halka arzın maliyetinin toplanan sermayenin \%2-5 bandında seyrettiğini ifade etmişlerdir. Tek seferlik bu maliyet sonrasında halka arz sonrası herhangi bir faiz yükü bulunmamaktadır. Bu anlamda banka finansmanına göre halka arz oldukça düşük bir maliyete sahiptir.

Bir diğer merak edilen soru ise halka arz sürecinin alacağı zamandır. 10 sektör profesyonelinin bu soruya verdiği cevap ise hazır firmalarda halka arz sürecinin 2-3 aylık bir zaman diliminde tamamlanabilmesi yönündedir. Organizasyonel ve operasyonel olarak hazır olmayan firmalar için ise süreç 1 yılı bulabilmektedir.

Şirketler halka arz sonrasında her yıl kar payı dağıtma zorunluluğunun bulunup bulunmadığını sorarken sektör profesyonelleri çalışmasında bu soruya alınan cevap böyle bir zorunluluğun bulunmadığı yönündedir. Borsalardaki genel seyre bakıldığında da halka arzından bu yana hiçbir zaman temettü dağıtmamış firmaların bulunduğu görülmektedir.

Halka arz sonrası ticari sır niteliğindeki bilgilerin kamu ile paylaşılacağı algısı şirket yöneticileri ile yapılan görüşmeden dikkat çekici boyuttadır. Sektör profesyonellerinin bu soruya yaklaşımları ise oldukça net olmuştur. Şirketlerin hiçbir ticari sırrı kamu ile açıklama zorunluluğu bulunmamaktadır. Ticari sırrın açıklanması sonrası firma ticari faaliyet açısından zor durumda kalacaksa hiçbir borsa yatırımcısı da bu durumdan memnun olmayacaktır. Kamuya açıklanan veriler ise genelde firmanın borsada sağlıklı fiyatlanabilmesi için gerekli olan faaliyet verileri ve mali tablolarıdır.

Türk şirketlerinin ortakları ve yöneticileri için en çok merak edilen soru ise halka arz sonrası şirketlerin ortaklık kontrolünün kaybedilip kaybedilmeyeceği yönündedir. Borsa İstanbul'a (BİST) bakıldığında ortalamada şirketlerin \%25'lik halka açıklığa sahip olduğu görülmektedir. Ayrıca halka arz öncesi kurucu ortak hisselerine sağlanan yönetim imtiyazı da bu problemi ortadan kaldırmaktadır.

\begin{tabular}{lr} 
Tablo 4: Sıkça Sorulan Sorular & Oran* \\
\hline Halka açılma maliyetli midir & $28 \%$ \\
Süreç uzun mudur & $12 \%$ \\
Her yıl temettü dağıtma zorunluluğu bulunmakta mıdır & $11 \%$ \\
Halka arz sonrası ticari sırlar kamu ile paylaşılacak mıdır & $48 \%$ \\
Halka arz sonrası ana ortak kontrolü kaybedecek midir & $35 \%$ \\
\hline
\end{tabular}

\footnotetext{
Kaynak: Şirket Ziyareti Verileri

*Oranların toplamının 100 etmemesinin sebebi katılımclların kesişen cevaplarıdır.
}

\section{4. Sermaye Piyasası Aktörleri}

10 sektör profesyoneli sektörün ana kurumlarını yapılan anket çalışmasında aşağıdaki gibi tek cümlelerle tanımlamışlardır. Halka arz sektöründe ana aktör ve düzenleyici otorite SPK'dır. Sermaye piyasalarındaki diğer tüm gruplar SPK mevzuatı çerçevesinde hareket etmekle yükümlüdürler. Borsa 
İstanbul ikincil otorite olarak şirketlerin hisse senedi veya diğer sermaye piyasası enstrümanlarının borsada işlem göreceği pazarın kotasyon şartlarından sorumludur. Ayrıca şirket hisselerinin işlem görebileceği pazarları ve pazarlar arası transferi belirleyen kurum Borsa İstanbul'dur. Merkezi Kayıt Kuruluşu şirket hisse senetlerinin borsada ihracı sonrası kaydileştirilmesinden sorumludur. Başka bir deyişle şirketler yeni hisse senedi ihraç ettiklerinde söz konusu satılan hisseler resmi bir otorite nezdinde kaydi bir sistemde yatırımcı adına takip edilir. Bu takip şirketlere bırakılmaz. Aracı kurumlar borsalarda satılan sermaye piyasası enstrümanlarının alınıp satılmasında aracı rolü üstlenirler. Ayrıca aracı kurumlardaki profesyoneller ve danışmanlar yatırımcılar adına yüksek finansal okuryazarlık yetenekleri ile portföy oluştururlar. Kamuyu Aydınlatma Platformu ise şirketlerin faaliyetleri ile ilgili verileri ve mali tabloları yatırımcıların analiz edebilmesi için yayınlayan resmi bir kurumdur.

Tablo 5: Sermaye Piyasası Aktörleri

\section{SPK}

Borsa İstanbul

Merkezi Kayıt Kuruluşu

Arac1 Kurumlar

Kamuyu Aydinlatma Platformu

Kaynak: Sektör Profesyonelleri Çalışması

\section{5. Halka Arz Şekli}

Halka arzlarda mevcut ortaklar kendi paylarını satabildiği gibi sermaye artırımı ile şirketler nakit girişi de sağlayabilmektedir. Bazı durumlarda ise karma yöntem uygulanmakta halka arzda hem ortak satışı hem de sermaye artışı gerçekleşmektedir (Bekçi vd., 2010: 35). 10 sektör profesyonelinden alınan bilgiye göre en çok uygulanan halka arz metotları sermaye artırımı, ortak satışı ya da ortak satışı ve sermaye artışı olarak sıralanmaktadır. Sektör yöneticilerinin hangi metodun piyasada algısının daha pozitif olduğuna yönelik soruya sermaye artırımı ya da sermaye artırımı ve ortak satışı karması olarak cevap vermesi dikkat çekicidir. Tüm yöneticiler ortak satışın piyasada kabul gören bir yaklaşım olmadığı yönünde hem fikirdir.

Buna göre halka arzda yatırımcıları sembolize eden aracı kurumlardan yurtiçi ve yurtdışı ayrı olmak üzere bir konsorsiyum oluşturulur. Konsorsiyum sözleşmesine imza atan tüm aracı kurumlar halka arza katılabilmekte ve yatırımcılarına hisse satışı gerçekleştirebilmektedir. 10 sektör profesyonelinin ortak görüşüne göre birçok kurum konsorsiyumda halka arz ürünlerinin kendi raflarında da yer alabilmesi için halka arza katılmayı tercih etmektedir. Konsorsiyumda bir lider ve bazen de bir eş lider yer almaktadır.

Sermaye artırımı yaklaşımında satılan hisse senedine karşılık şirketin bünyesine nakit girişi gerçekleşirken ortak satışında mevcut ortaklar sahibi oldukları hisse senetlerini borsadaki diğer yatırımcılara devretmektedirler.

\section{6. Fiyatlama Metodolojileri}

10 sektör profesyonelinden alınan bilgiye göre en çok uygulanan 2 yaklaşım indirgenmiş nakit akışı ve piyasa çarpanlarıdır. Son yıllarda piyasa çarpanları ön plana çıkarken aracı kurumlar indirgenmiş nakit 
akımları yönteminden uzaklaşmışlardır. Sektör yöneticileri bu durumu indirgenmiş nakit akımı metodunda gelecek beklentisinin bulunmasına ve birçok yabancı yatırımcı için bu durumun bir beklenti ve dava konusu olabilecek bir yükümlülük gibi görülmesine bağlamaktadır. Özellikle İngiliz hukukuna dayanak gösterip geçmişte birçok yabancı yatırımcı şirketin öngördüğü beklentiler gerçekleşmeyince şirketlere uluslararası davalar açmışlardır.

İndirgenmiş nakit akımı analizinde şirketin gelecek 5 ya da 10 yıldaki nakit akışları tahmin edilip bugüne indirgenirken piyasa çarpanlarında benzer şirketlerin mali verileri ve piyasa değerlerine göre değer tespiti yapılmaktadır.

Tablo 6: Fiyatlama Metodolojileri

İndirgenmiş Nakit Akımları

Piyasa Çarpanları

Net Aktif Değer

Ekspertiz Değerleme Yaklaşımı

Temettü Verimi Yaklaşımı

Kaynak: Sektör Profesyonelleri Çalışması

\section{7. Halka Arz Maliyetleri}

SPK kurul kayıt ücreti, Borsa İstanbul ücreti, Merkezi Kayıt Kuruluşu ücreti, yatırım danışmanlığı ücreti, aracı kurum satış komisyonu, bağımsız denetim, hukukçu raporu, ekspertiz raporu, reklam ve tanıtım masrafları 10 sektör profesyonelince yapılan anket çalışmasında belirlenen halka arz maliyet başlıklarıdır. Buna göre halka arzın maliyeti elde edilen nakit girişinin \%2-5 bandında hareket ederken nakit girişi arttıkça oran \%2'ye yakınsamaktadır.

Tablo 7: Halka Arz Maliyetleri

\section{SPK}

Borsa İstanbul

MKK

Arac1 Kurum

Bağımsız Denetim

Hukukçu Görüşü

Eksper Firmas1

Reklam
Kayda alınan ve satılan senetlerin $\% 0,2^{\prime} i$ Sermayeni Nominal Tutarının $\% 0,1$ 'i Ödenmiş sermayenin $\% 0,1^{\prime} i$ Nakit girişinin \%1,5-\% 4,5 'i 10.000-50.000 TL

Belirtilmedi

Belirtilmedi Belirtilmedi

Kaynak: Sektör Profesyonelleri Çalışması

3. 8. Halka Arz Sonrası Şirketin Yükümlülükleri

Halka açılan şirketler borsalarda işlem gördükleri süre boyunca yatırımcılarına bilgi verme yükümlülüğündedirler (Karaa ve Akakçe, 2017: 376). 10 sektör profesyoneline göre halka arz sonrası şirket, 6 aylık ve yıllık bağımsız denetim yükümlülüğüne maruz kalacaktır. Şirketler, ara dönemlerde ise bağımsız denetimi yapılmamış, uluslararası finansal raporlama standartları ile uyumlu mali tabloyu kamu ile paylaşacaklardır. Şirketler, yüksek oranda hisse devirlerini, önemli nitelikteki iştirak, gayrimenkul alımsatımlarını, yatırım planlamalarını sektör ve şirketin faaliyetine yönelik veri ve beklentileri yatırımcılarla özel durum açıklaması formatında paylaşmakla yükümlü olacaklardır. Şirketler, kurumsal yönetimlerini 
SPK'nın yayımladığı tebliğe uygun hale getirecek ve SPK talep ederse temettü dağıtmaya mecbur olacaklardır. Piyasa yöneticilerine göre SPK'nın temettü dağıtımına yönelik zorunlu bir uygulaması ise son 10 yılda gerçekleşmemiştir. Ancak piyasada nakit sıkışıklığı olması halinde SPK şirketlerden temettü dağıtmalarına yönelik bir genelge yayımlayabilir.

\section{9. Halka Arz Süreci}

Sektör profesyonellerine göre halka arz sürecinde şirket ve aracı kurumun alması gereken aksiyonlar ayrı ayrı takip edilmelidir. Aracı kurumun en önemli aksiyonu fiyat tespit raporunun hazırlanıp hisse satışının gerçekleşmesi olarak belirtilirken şirket için doğru danışmanların seçilmesi oldukça önemli adımlar olarak tanımlanmaktadır. Her iki taraf için alınması gereken adımlar aşağıdaki tabloda özetlenmiştir.

Tablo 8: Halka Arz Edilen Şirketin Aksiyonları

Bağımsız Denetim Firmasının Belirlenmesi

Konsorsiyum Lideri Seçilmesi

Yabancı Satış İçin Aracı Kurumun Seçilmesi

Şirketin Organizasyonel Yapısı ve İlişkili Taraf İşlemlerinin Düzenlenmesi

Hukukçunun Belirlenmesi

Halkla İlişkiler Danışmanının Belirlenmesi

Kaynak: Sektör Profesyonelleri Çalışması

Tablo 9: Aracı Kurumun Aksiyonları

BİST ve SPK Taleplerinin Yönetimi

İzahnamenin Hazırlanması

BİST Dokümanlarının Hazırlanması

Fiyat Tespit Raporunun Hazırlanması

Analist Sunumunun Hazırlanmas1

Hukuk Bürosu-Denetim Firması-Halkla İlişkiler Bürosunun Koordinasyonu

Konsorsiyumun Kurulmas1

Talep Toplama ve Satış

Kaynak: Sektör Profesyonelleri Çalışması

\section{10. Halka Arz Takvimi}

10 sektör profesyonelinin yaklaşımına göre ortalamada halka arz takvimi 15-17 hafta olarak belirlenmiştir. Firmanın daha önce bağımsız denetim açıklamıyor olması süreci bir miktar daha uzatabilmektedir. Şirketin değerine yönelik tüm değerleme çalışmaları ve yatırımcı sunumları bağımsız denetim sonrası gerçekleştirilebilmektedir. Borsa İstanbul ve SPK dokümanlarının hazırlanması için ortalamada 6-8 hafta gerekebilmektedir. Ayrıca Borsa İstanbul ve SPK yetkilileri ayrı ayrı şirketi ortalamada 2 ya da 3 gün olmak üzere ziyaret edebilmektedirler. Genelde hisse satışı 2 gün sürmekle birlikte pazarlama faaliyetleri satıştan 1 ay önce başlayabilmektedir.

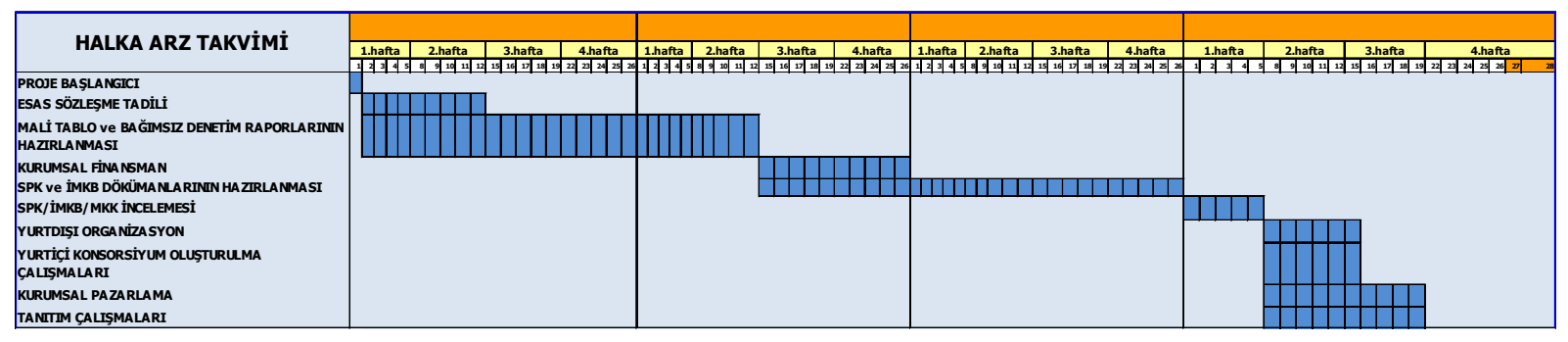




\subsection{Kotasyon Şartları}

Borsada işlem görmeye başlayan şirketler için farklı pazarlar tanımlanmıştır ve şirket hisse senetleri şartlarını sağladığı pazarda işlem görebilmektedir. Buna göre şartlar aşağıdaki şekilde özetlenebilir. Söz konusu şartlar değerlendirilirken bağımsız denetimden geçmiş mali tablolar kullanılmaktadır (Borsa, 2015: 46).

\begin{tabular}{|c|c|c|c|}
\hline $\begin{array}{l}\text { Tablo 10: Araci } \quad \text { Kurumun } \\
\text { Aksiyonları }\end{array}$ & $\begin{array}{ll}\text { Yildiz } & \text { Pazar } \\
\text { Grup 1 } & \end{array}$ & $\begin{array}{l}\text { Y1ldiz Pazar } \\
\text { Grup } 2\end{array}$ & $\begin{array}{l}\text { Ana Pazar } \\
\text { Grup 1 }\end{array}$ \\
\hline $\begin{array}{l}\text { Halka Arz Edilen Payların Piyasa } \\
\text { Değeri }\end{array}$ & $\begin{array}{l}\text { Asgari } \\
1.000 .000 .000 \\
\text { TL }\end{array}$ & $\begin{array}{l}\text { Asgari } \\
150.000 .000 \\
\text { TL }\end{array}$ & $\begin{array}{l}\text { Asgari } \\
30.000 .000 \\
\text { TL }\end{array}$ \\
\hline $\begin{array}{l}\text { Yillık finansal tablolarında dönem } \\
\text { kârı olması }\end{array}$ & Son 2 Y1l & Son 2 Yil & Son 2 Y1l \\
\hline Öz sermaye/Sermaye Oranı & 0,75 'ten Büyük & 1'den Büyük & \begin{tabular}{|l|}
1,25 'ten \\
Büyük \\
\end{tabular} \\
\hline $\begin{array}{l}\text { Halka arz edilen payların nominal } \\
\text { değerinin sermayeye asgari oranı }\end{array}$ & - & $10 \%$ & $20 \%$ \\
\hline
\end{tabular}

3. 12. Başarılı Bir Halka Arzın Temel Özellikleri Arac1 kurum ve portföy yönetim şirketlerinden 10 sektör

profesyoneli ile yapılan ziyaret ve anket çalışması sonrası başarılı bir halka arzı tanımlamaları istenmiş ve en çok öne çıkan başlıklar aşağıdaki tabloda özetlenmiştir.

Tablo 11: Başarılı Bir Halka Arzın Özellikleri

Borsada Belirsizliğin Azalması

Sektöre Dair Olumlu Gelişmeler

Mali Verilerdeki Başarı

Gelecek Olumlu Beklentiler

Yakın Zamandaki Başarılı Halka Arzlar

Şirketin Yatırım Hikayesi

Güçlü Yönetim

Ortak Satışından Ziyade Sermaye Artırımı

Sürdürülebilir Kar ve Temettü Politikası

Cazip Değerleme Çarpanları ve Uygun Hisse Fiyatı

Kaynak: Sektör Profesyonelleri Çalışması

\section{GERÇEK HALKA ARZ ÖRNEKLERİ}

\section{1. Fiyatlama ve Performans}

Son yıllarda gerçekleştirilen halka arz sayısının oldukça düşük ve tekil olması nedeniyle halka arz furyasının önemli bir seviyede olduğu 2013 yılı halka arzları incelenmiştir. 2013 yılında birçok farklı sektörden halka arzdan önemli tutarda nakit girişi sağlanmıştır. Pegasus, Royal, Odaş, Tümosan ve Akyürek şirketlerinin 2013 yılında gerçekleştirdikleri halka arz verileri, fiyatlama çarpanları ve piyasa değerleri 
aşağıdaki tabloda özetlenmiştir. Bu şirketlerin fiyat tespit raporu incelendiğinde genellikle FD/FAVÖK ve F/K çarpanları ile halka arz fiyatı tespit edilirken beklenti çarpanları ve cari çarpanlar bir arada kullanılmıştır. Kimi halka arzlar yapıldıkları tarihten bu yana yatırımcısına önemli bir getiri sağlarken bazıları hayal kırıklığı yaratmıştır.

Tablo 12: 2013 Yılında Yapılan Arzlarda Para Girişi Hariç Halka Arz Çarpanları

\begin{tabular}{|c|c|c|c|c|c|c|}
\hline Şirket & $\begin{array}{l}\text { Halka Arz } \\
\text { Tarihi }\end{array}$ & $\begin{array}{l}\text { FD/FAVÖK- } \\
\text { Cari }\end{array}$ & $\begin{array}{l}\text { FD/FAVÖK- } \\
\text { 2013T } \\
\text { Beklenti }\end{array}$ & $\begin{array}{l}\text { F/K 4Ç- } \\
\text { Halka } \\
\text { Arz }\end{array}$ & $\begin{array}{l}\mathrm{F} / \mathrm{K} \\
\text { 2013T - } \\
\text { Beklenti }\end{array}$ & $\begin{array}{l}\text { Halka Arz } \\
\text { Piyasa Değeri }\end{array}$ \\
\hline Pegasus & 26.04 .2013 & 8,46 & m.d. & 10,93 & m.d. & 1.380 .000 .000 \\
\hline Royal & 3.05 .2013 & 5,49 & 4,85 & 5,31 & 6,32 & 222.500 .000 \\
\hline Odaş & 21.05 .2013 & 8,12 & 4,98 & 10,27 & 6,00 & 150.000 .000 \\
\hline Tümosan & 5.12 .2012 & 9,72 & 4,87 & 12,77 & 6,77 & 420.000 .000 \\
\hline Akyürek & 6.06 .2013 & 8,47 & m.d. & 11,61 & m.d. & 84.725 .525 \\
\hline Ortalama & & 8,05 & 4,90 & 10,18 & 6,37 & \\
\hline
\end{tabular}

Halka Arz Sonrası ODAS \& BIST 100 Getiri

Karşılaştırması

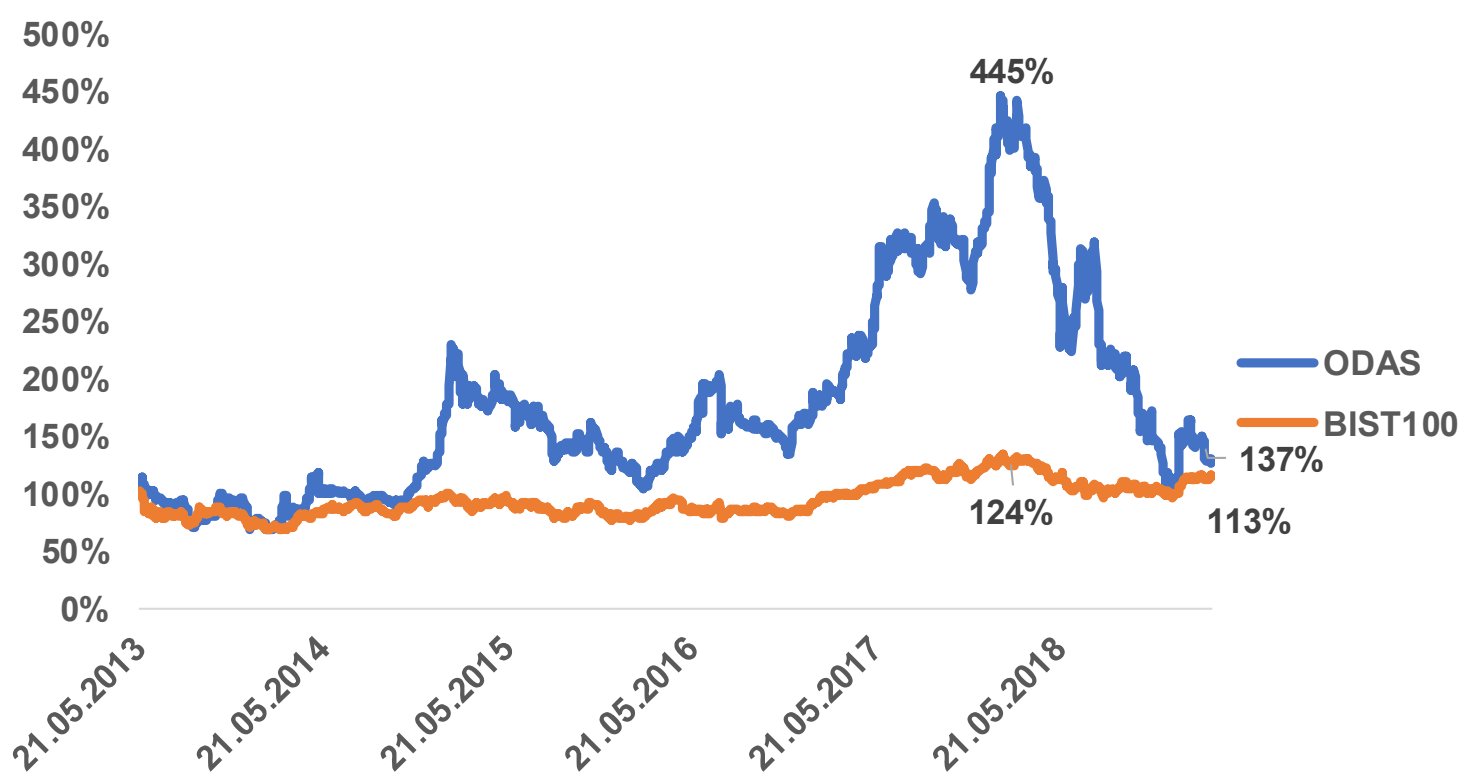

Şekil 1: Halka Arz Sonrası ODAS \& BIST 100

$250 \%$

Halka Arz Sonrası EKIZ \& BIST 100 Getiri

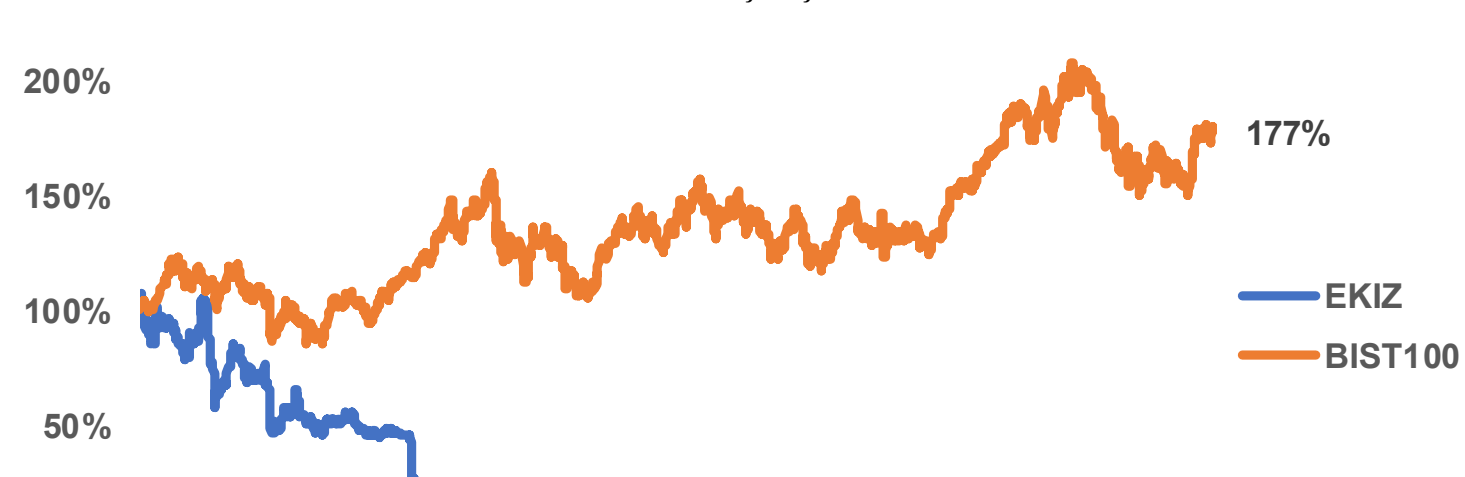




\section{SONUÇ}

Son yıllarda bankacılığa dayalı bir ekonomik büyümenin sanayi devrimi sonrası teknoloji devrimini yakalayamadığı şeklinde bir algı güçlenerek büyümektedir. Sermaye piyasaları denildiğinde ilk akla gelen ürün hisse senedinin halka arzıdır. Tahvil-bono ya da kira sertifikalarının da halka arzı gerçekleşmekle birlikte en çok uygulanan halka arz şirketlerinin hisse senedidir. Halka arz şirketlerin hisse senedinin genel olarak halka satış çağrısı olarak tanımlanmaktadır. Türkiye'de hisse halka arzı oldukça nadir karşılaşılan bir olgudur. Son dönemde sermaye piyasalarına olan gelişen pozitif bir trend ile halka arz adetlerinin artırılması amaçlanmaktadır. Böyle bir konjonktürde çalışmamız hisse halka arzı gerçekleştirmek isteyen kuruluşlar için önemli sorulara cevap vermektedir. Çalışmamızda sanayi ve hizmet sektöründe faaliyet gösteren 20 şirketin yöneticileri ile görüşmeler yapılmış ve halka arza bakış açıları belirlenmeye çalışılmıştır. Aracı kurum ve portföy yönetim şirketinden 10 profesyonel üzerinden kısa anketler gerçekleştirilmiş ve şirketlerin merak ettiği halka arz sürecine dair tüm sorular cevaplanmaya çalış1lmıştır.

Şirketler halka arzın en temel faydalarını hisselere sağlanan likidite, ucuz finansman ve stratejik ortağa ulaşımı kolaylaştırma aracı olarak tanımlamışlardır. Şirketlere göre halka arzın en önemli problemleri ise ticari sır niteliğinin azalması ve artan denetimlerdir. Şirketlerin halka arz ile ilgili en çok sordukları sorular ise tüm ticari sırların kamuyu aydınlatma platforumunda yayınlanıp yayınlanmayacağı, halka arz sonrası ana ortağın şirket üzerindeki hakimiyetin korunup korunamayacağı, halka arz sürecinin maliyeti ve temettü zorunluluğunun olup olmaması olarak belirlenmiştir. Bu anlamda halka arza aday firmaların endişe duyduğu konular hakkında kurumsal bir bilgilendirmeye ihtiyaç duydukları açıktır. Borsa İstanbul A.Ş. yetkililerinin söz konusu firmaları sürekli olarak bilgilendirmeleri şirketlerin halka arza olan bakış açısını değiştirebilecektir.

Son bölümde ise 2013 yılında halka arzı gerçekleştirilen şirketlerin fiyatlama metodolojileri kamuyu aydınlatma platformunda yayınladıkları imzalı fiyat tespit raporlarından incelenmiş ve ilgili paydaşlar ile çalışmamızda özetlenmeye çalışılmıştır. Ayrıca başarılı ve başarısız bir halka arzında gerçek performansı da çalışmamızda özetlenmiştir.

Yapılan halka arzların fiyatlamasında son dönemde gelecek nakit akışlarının tahmin edildiği indirgenmiş nakit akımları metodu yerine şirketin son dönemde açıkladığı mali veriler ve sektörün fiyatlama çarpanlarına göre değer belirleyen piyasa çarpanlarına göre şirket değerleme yaklaşımının kullanıldığı anlaşılmıştır. $\mathrm{Bu}$ durumda en önemli sebep firmaların söz konusu nakit akış beklentilerinden dolayı gelecekte özellikle yabancı yatırımcılar nezdinde sorumlu olmak istememeleri olarak görülmektedir. Şirket değerlemelerinde şirket yönetimlerinin gelecekte bekledikleri karlılı̆̆ın yatırımcılarla açık bir şekilde paylaşılmasının önem arz ettiği düşünülmektedir. Bu anlamda değerleme yaklaşımlarında kısmi de olsa indirgenmiş nakit akımları metodunun kullanılmasının SPK tarafından zorunlu hale getirilmesi salık verilmektedir.

Sermaye piyasalarına dayalı ekonominin daha üretken olduğu düşünüldüğünde hisse halka arzlarının önümüzdeki dönemde artacağı beklenmektedir. Ayrıca bankalardaki mevduat sınırlarının zirveye ulaşması ile bankacılık finansmanında önemli bir darboğaza ulaşıldığı sektör profesyonellerince beklenmektedir. Halka arz fiyatlamasında son yıllarda indirgenmiş nakit akımı analizinin yerini piyasa çarpanlarına bıraktığı dikkat çekmektedir. $\mathrm{Bu}$ durumda indirgenmiş nakit akımları yaklaşımında şirketin gelecek karlarının özellikle yabancı yatırımcı nezdinde bir yükümlülük oluşturması algısı güçlü olmuştur. Bazı halka arzlar başarılı bir şekilde getiri performansı sağlarken kimi halka arzlarda sermaye önemli oranda erimiştir. Bu durum birçok yatırımcının halka arza katılsa bile portföy çeşitlendirme yapmasını önemli kılarken ilgili 
otoritelerin halka arz edilen şirketlerin denetimini daha detaylı yapması gerektiği sonucunu da beraberinde getirmektedir.

\section{KAYNAKÇA}

Ang, J., \& Brau, J. "Firm Transparency and The Cost of Going Public". The Journal of Financial Research. (2002), 1-17.

Bekçi, İ., Özboyacı, M., \& Negiz, N. "Halka Arzın Şirketlerin Performansı Üzerine Etkisi ve İMKB'de Bir Uygulama". Süleyman Demirel Üniversitesi Vizyoner Dergisi. (2010), 33-52.

Borsa, İ. "Kotasyon Yönergesi". İstanbul: Borsa İstanbul.(2015).

Chemmanur, T., \& Fulghieri, P. "A Theory of the Going-Public Decision". The Review of Financial Studies Summer. (1999), 249-279.

Jensen, M., \& Meckling, W. "The Theory of the Firm: Managerial Behavior, Agency Costs, and Capital Structure". Journal of Financial Economics. (1976), 305-360.

Karaa, İ.E. "Yatırımcıların Hisse Getirisi Beklentileri Üzerinde Geçmişin Gölgesi: Geçmiş Ekstrapolasyonu". Yönetim ve Ekonomi. (2017), 151-168.

Karaa, İ., \& Akakçe, G. "Türkiye'de Firmalarin Halka Arzdan Çekilme Nedenleri ve Sonuçları". Journal of Business Research Turk. (2017), 375-392.

Kiymaz, H. "The initial and Aftermarket Performance in an Emerging Market: Evidence from Istanbul Stock Exchange". Journal of Multinational Financial Management. (2000), 213-227.

Küçükkocaoğlu, G. "Underpricimg in Turkey: A Comparison of the IPO Method". International Research Journal of Finance and Economics. (2008), 162-182.

Ozer, B. "Price Performance of Initial Public Offering in Turkey". Ankara: Capital Market Board of Turkey. (1999).

Pastor, L., \& Veronesi, P. "Rational IPO Waves". The Journal of Finance. (2005), 1713-1757.

Ritter, J. R. "The Costs of Going Public". Journal of Financial Economics. (1987), 269-281.

Ritter, J., \& Welch, I. "A Review of IPO Activity, Pricing, and Allocations". The Journal of Finance. (2002), 1795-1823. 448.

Zingales, L. "Insider ownership and the decision to go public". Review of Economic. (1995), $425-$ 